IJMS 2018 vol. 5 (1): 37 - 52

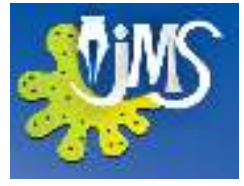

International Journal of Multidisciplinary Studies (IJMS)

Volume 5, Issue 1, 2018

DOI: http://doi.org/10.4038/ijms.v5i1.111

\title{
Effect of Land related Factors on Smallholder Cropping Systems in Rural Sri Lanka
}

\author{
Thennakoon TMSPK \\ Department of Geography, University of Sri Jayewardenepura, Sri Lanka.
}

\begin{abstract}
There are marked differences between the Wet and Intermediate Zones of Sri Lanka in the type of crops selected and cropping practices used by smallholder farmers. This study was specifically geared to i) identify the major smallholder cropping systems in the study area, ii) analyze the relationship between land size and cropping intensity, and iii) to determine how land size, land ownership, proximity to land from the homestead influences the selection of different cropping systems. Data and information were collected from a sample of 96 households in the four selected villages representing each from Kalutara, Kegalle, Moneragala and Hambanthota districts using semi structured interviews, direct observations, case studies and farm sketches. Data were analyzed using a variety of statistical methods including chisquare and general linear model. The study found that the allocation of land for the selected crops was lower in the villages of Kegalle and Kalutara districts compared to the Moneragala and Hambanthota. The study also ascertained that an increase in land size resulted in a decrease in the number of crops grown and cropping intensity in home gardens and rubber smallholdings. Also lower priority was given to intercropping of rubber smallholdings by farmers owned with more than 2 acre of land available, and vice versa. The income level of the household had a considerable influence on several factors including, selection of cropping systems, size of land holding, and allocation of land to different crops. Variation in land ownership between villages had a significant effect on the establishment of crops $(p<0.001)$ i.e. owner-cultivated smallholdings comprised a mixture of many short term and permanent crops while tenant cultivated smallholdings consisted solely of short-term crops. Distance of the land from the homestead had a significant effect on the selection or non-selection of cropping systems. Consequently, crops with less risk and maintenance were grown further out from homestead (e.g. citronella) and rubber compared to banana and tea. Similarly, the form of land smallholdings consisted of a mixture of intercrops (including other permanent crops), and soil protection methods were practiced, whereas tenanted farms had seasonal intercrops with less attention paid to soil protection and improvement.
\end{abstract}

KEYWORDS: Land ownership, Proximity, Land size, Smallholders, Cropping systems

Corresponding author: T.M.S.P.K. Thennakoon, Email: sunethrapk@sjp.ac.lk, sunethrapk@gmail.com 


\section{INTRODUCTION}

There is overwhelming evidence that smallholder cropping systems in Sri Lanka are strongly influenced by major socio-economic factors together with the biophysical environment. There are two aspects of land that are important to smallholder livelihoods: i) land provides the basis for agricultural productivity and ii) there may be non-agricultural economic value of land to the household. There are marked differences between the Wet and Intermediate Zones of Sri Lanka in the type of crops selected and cropping practices used by smallholder farmers. This is probably due in part to variation in land availability and hence size of land holdings, quality of land, the form of land ownership, the distance between farm and homestead and accessibility to water facilities associated with land. Differences in the above variables amongst agro-climatic zones, villages or households are influenced by several socio-economic factors. Population density, government policies on land distribution and proximity to urban areas may influence the variation in land size at village or zone level, whilst traditional systems of land ownership and the present income level of a particular household have major influences on land at the household level (Pomp, 1995). Various land use systems, including permanent, semi-permanent, seasonal crop and home garden crops, can be found at the smallholder level in Sri Lanka and under each different land use practices are evident (Thennakoon, 2002). Although numerous researchers in other countries have pointed out that land related factors such as size, ownership, type and proximity of the land hold an important role in the selection of different crops, cultivation methods, as well as land productivity, a few socio-economic study have been undertaken in
Sri Lanka. Therefore, the study reported here was specifically geared to i) identify the major land use systems in the study area, ii) analyze the relationship between land size and cropping intensity, and iii) to determine how land size, land ownership, proximity to land from the homestead influences the selection of different cropping systems.

\section{LITERATURE REVIEW}

Depending on the availability of land and income levels in a particular household, cropping practices may vary. A decrease in land size may influence smallholder cropping systems in two ways. Firstly, farmers may respond by increasing the land use intensity through cultivating many crops on the same land simultaneously or sequentially or secondly they may invest in land productivity by improvement of soil fertility (Grisley and Mwesigwa, 1994). Several authors have observed that farmers with less land (ca. $<1$ ha) tend to use the land more intensively by growing many varieties of crops on the same land plot in order to gain the maximum income (Pagiola et al., 2001). In contrast, farmers with more land (ca. $>1$ ha) tend to cultivate mono crops on different plots of land. The level of yield alters in concert with land size, because farmers with small land holdings manage land more intensively, resulting in high yield. Cropping intensity can frequently be seen in rubber based intercropping, home gardens and chena cultivation (slash and burn farming) in Sri Lanka. However, this may vary amongst households within and amongst villages, due in part to variations in the income level and other socio-economic endowments of households. For example, traditionally, chena cultivation was the major livelihood pattern of farmers in the 
Dry and Intermediate Zones, but when the population started to increase agriculture became more settled and intensive, ending up with short-term crops without slashing and burning land or a fallow period. This may have a negative influence on soil conditions due to long-term cultivation on the same land without an effective fallowing period, soil erosion may increase and soil fertility decrease (Ranabahu, 1998).

Generally, farmers' decisions on what cropping pattern to select and what methods to use to improve soil fertility depend on the form of land ownership. Several authors have observed that uncertainty of land ownership influences the selection of different crops for smallholdings (Gray, 1997). For example, farmers who own their land seem to grow many crops using new technologies, in contrast farmers who cultivate land under tenancy or contracts tend to cultivate only short-term crops which can be harvested within the contract time period. Several authors have confirmed that due to variation in land management, land productivity may differ amongst different types of land ownership (Buckles and Triomphe, 1999; Comhiel et al., 1999). For example, fertilizer use was higher for rice plots cultivated by owners than tenanted plots (Soule et al., 2000). The distance between land and the homestead also influences the selection of crops and depends on the level of susceptibility of the crop to animal damage and theft. For example, crops such as banana, vegetables and tuber crops (Diascorea spp) are grown close to the homestead. In addition, the level of maintenance may also influence the selection of crops for different locations.

\section{RESEARCH METHODOLOGY}

Four villages, two from the intermediate Zone (Pallekiruwa and Bookandayaya) and two from the Wet Zone (Kobawaka and Pannila) were selected for case studies undertaken during the study in 2014. A selection of permanent (rubber and tea), semi permanent (banana and citronella grass), home garden (pepper and arecanut) and seasonal (paddy and chena crops) crops provided the basis for assessing different cropping systems across agro-climatic Zones. Stratified random sampling was used to obtain a representative sample. A sample of 24 households from each village including at least three households with each major cropping system was selected. Two different types of data were collected; quantitative information such as land area allocated to each crop and smallholding, number of crops in the home garden and proximity of the land to the homestead and qualitative information such as people's perception of their income status, the availability of government land, soil erosion, soil fertility and the present status of different farming systems. To collect data, four different methods were employed; semi structured interviews, direct observation, case studies and farm sketches. Data were analyzed using a variety of statistical methods including chisquare and general linear model (GLM).

\section{RESULTS}

\subsection{Spatial variation of land size and land ownership}

Figure 1 summarises the average land holding in each of the four villages, with GLM analysis indicating that land size differed significantly between villages $(\mathrm{p} \leq 0.01)$, being larger in the Intermediate than in the Wet Zone villages. 


\section{T.M.S.P.K. Thennakoon}

Table 1 shows the different forms of land ownership in the selected villages. Chi-square tests indicated that there was a significant association between land ownership and village location, $\mathrm{X}^{2}(\mathrm{~N}=96, \mathrm{df}=9)=115.57, \mathrm{p}<0.001$ (Table 1).

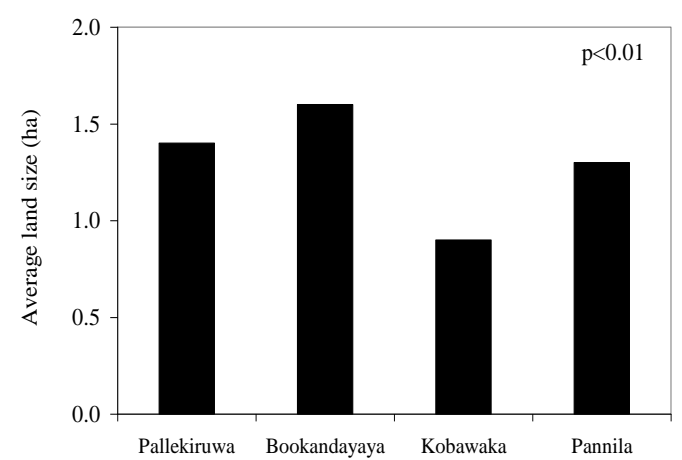

Figure1. Average land size (ha) per household in each of the four selected villages; Pallekiruwa, Bookandayaya (Intermediate), Kobawaka and Pannila (Wet).

\subsection{Present status of cropping systems}

Table 2 summarises the present cropping systems in the four selected villages. There was a significant variation between households engaged in various cropping systems and village locations $(\mathrm{p}<0.001)$. Rubber based cropping systems and banana was common to all villages, whilst tea and chena crops were cultivated only in the Wet Zone and the
Intermediate Zone, respectively. The percentage of households cultivating rubber was over twofold greater in Pallekiruwa than Bookandayaya, whilst a similar percentage of households ( $c a$. $85 \%$ ) cultivated rubber in the villages of the Wet Zone. Banana was cultivated by $100 \%$, $56 \%, 50 \%$ and $66 \%$ of households in Pallekiruwa, Bookandayaya, Kobawaka and Pannila, respectively. Chena crops were restricted only to villages of the Intermediate Zone whilst paddy was cultivated by $83 \%$ and $70 \%$ of households in Pallekiruwa and Kobawaka, with no paddy grown in Bookandayaya. Tea was grown only in the Wet Zone by $20 \%$ and $58 \%$ of households in Kobawaka and Pannila, respectively. 
Table 1: Summary of chi-square analysis comparing villages in terms of type of land ownership. Data presented as an absolute number of smallholdings falling into each group of land ownership. Data in parentheses are the percentages of the total number of smallholdings.

\begin{tabular}{|l|c|c|c|c|}
\hline \multirow{2}{*}{ Village } & \multicolumn{4}{|c|}{ Land ownership } \\
\cline { 2 - 5 } & State own & Private & Reservation & Shared \\
\hline Pallekiruwa & $39(81)$ & $50(26)$ & 0 & $1(14)$ \\
\hline Bookandayaya & $5(11)$ & $41(21)$ & $12(100)$ & 0 \\
\hline Kobawaka & 0 & $55(29)$ & 0 & 0 \\
\hline Pannila & $4(8)$ & $46(24)$ & 0 & $6(86)$ \\
\hline Total & 48 & 192 & 12 & 7 \\
\hline P value & \multicolumn{5}{|c|}{90.001} \\
\hline Chi-square value & \multicolumn{5}{|c|}{90.57} \\
\hline Degrees of freedom & \multicolumn{5}{|c|}{9} \\
\hline
\end{tabular}

Table 2. Number of households in each village engaged in different cropping systems. Data are presented in terms of the absolute number of households in each sub-sample (i.e. 24) together with the percentage in parentheses. Results from the chi-square tests are shown where DF represents the degrees of freedom. A two-way chi-square analysis was performed using the null hypothesis that there was no association between villages and the households grown each crop.

\begin{tabular}{|l|c|c|c|c|}
\hline & Pallekiruwa & Bookandayaya & Kobawaka & Pannila \\
\hline Rubber & $22(92)$ & $10(42)$ & $21(88)$ & $20(83)$ \\
\hline Intercropping & $18(75)$ & $4(17)$ & $7(29)$ & $7(29)$ \\
\hline Tea & - & - & $5(20)$ & $14(58)$ \\
\hline Banana & $24(100)$ & $14(58)$ & $12(50)$ & $16(66)$ \\
\hline Citronella grass & - & $17(70)$ & - & - \\
\hline Chena crops & $23(95)$ & $17(70)$ & - & - \\
\hline Paddy & $20(83)$ & - & $17(70)$ & $6(25)^{1}$ \\
\hline Chi-square value & \multicolumn{5}{|c|}{20.27} \\
\hline P value & \multicolumn{5}{|c|}{3} \\
\hline DF & \multicolumn{5}{|c|}{} \\
\hline
\end{tabular}

Note: 1 those households owned 3.5 ha of paddy land which were left uncultivated. 


\subsection{Factors determining smallholder cropping systems}

\subsubsection{Land size}

There was a significant difference in average land size (ha) between villages. Average land size of crops common to villages in both zones was greater in the villages of the Intermediate than the Wet Zone, except for rubber. Also, there were marked differences in the average land size of tea and chena crops even within similar zones for example, chena lands were greater (0.4 ha) in Pallekiruwa than Bookandayaya (0.3 ha) whilst tea lands were slightly larger in Pannila (0.5 ha) than Kobawaka (0.4 ha).
Pallekiruwa, Bookandayaya, Kobawaka and Pannila, respectively (Table 3).

Study ascertained the relationship between the number of crops grown in a home garden and size of the home garden (ha). The number of crops grown for a given area was strongly dependent on the land size $\left(r^{2}=0.915\right)$, when land size was $<0.2$ ha, then between 10 and 11 crop types were grown whereas when land size was $>1$ ha, between 3 to 4 varieties of crops were grown in an area of $16 \mathrm{~m}^{2}$ area (Figure 2). The size of tea holdings was larger in Pannila than Kobawaka, not only because of the greater availability of land, but also because of the greater availability of markets, ability to allocate material input and labour, and level of farmer knowledge (Thennakoon, 2017; Thennakoon, 2018).

Table 3. Comparison of the average size of land (ha) allocated to different crops in the four villages. A GLM was used to analyse the interactions between land size and crop type and land size, crop type and village location and p value presented

\begin{tabular}{|l|c|c|c|c|}
\hline \multicolumn{1}{|c|}{ Crop type } & Pallekiruwa & Bookandayaya & Kobawaka & Pannila \\
\hline Banana & 0.3 & 0.3 & 0.08 & 0.1 \\
\hline Chena crops & 0.4 & 0.3 & - & - \\
\hline Citronella grass & - & 1.3 & - & - \\
\hline Home garden & 0.8 & 0.6 & 0.2 & 0.3 \\
\hline Paddy & 0.4 & - & 0.2 & 0.2 \\
\hline Rubber & 0.4 & 0.3 & 0.7 & 1.1 \\
\hline Tea & - & - & 0.4 & 0.5 \\
\hline Total land (ha) & 35 & 33 & 28 & 32 \\
\hline Land size*crop type & \multicolumn{4}{|c|}{$\mathrm{p}<0.001$} \\
\hline
\end{tabular}

There was a significant relationship between land size and crop type $(\mathrm{p}<0.001)$. Extent of the land use was closely associated with the crop type. Rubber generally was grown on larger sized land, whilst opposite was true for banana. The total land in each village, including all selected crops was 35, 33, 28 and 32 ha in
Although rubber was introduced at more or less the same time to both villages in the Wet Zone, land size was greater in Pannila than Kobawaka, due to greater land (RRISL, 1992). As less land was available in the Wet Zone, competition for land was intense with the result that permanent cash crops such as rubber and tea were favored over short-term crops such as 
banana, although farmer priorities and labour availability had an effect on this decision. Banana cultivation was more common in the villages of the Intermediate Zone (Kudagamage, 2002) where land for establishing banana monocrops was readily available.

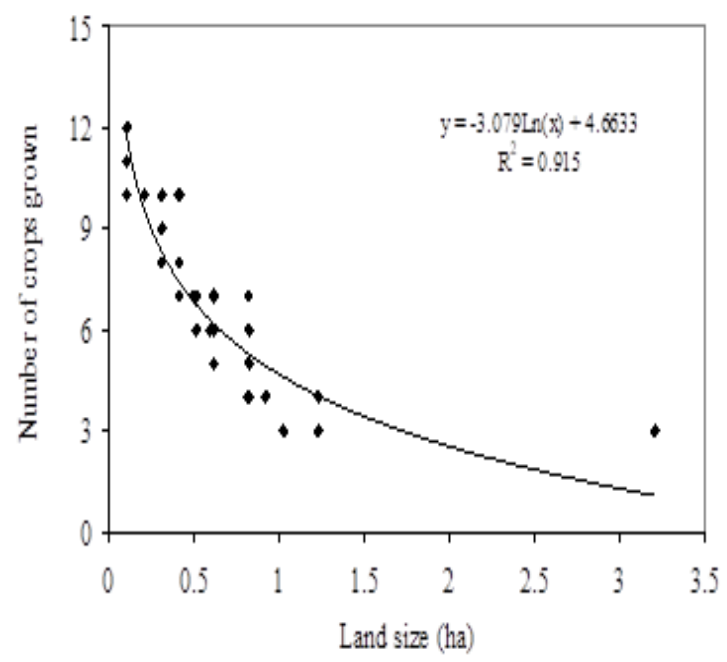

Figure 2. Relationship between the land size of home gardens and the number of crops grown. The number of crops grown was measured in a sample area of $16 \mathrm{~m}^{2}$ within each home garden. Data were presented on the basis of individual smallholdings with a total of 96 observations. Trend lines represent the logarithmic functions fitted to the data points.

Figure 3 illustrates how farmers can intensify the use of a limited amount of land ( $<1 \mathrm{ha})$. In order that the land meets the main objectives of smallholders in terms of subsistence and provision of incidentals, income and fixed assets the following crops are generally grown:

1. Permanent income: rubber is the principal crop and arecanut, pepper and garcinia (Garcinia gummi-gutta) are also grown on the boundaries of the land,
2. Subsistence: cereals (maize and millet), tuber crops (katuala (Diascorea pentaphylla), gahala (Colocasia)) and foliage crops such as kirianguna (Dregea volubilis), mukunuwenna (Sesilips triandra), gotukola (Hydrocotyle cantella asiatica),

3. Short-term cash crops: fruits such as banana, papaya and pineapple, vegetables such as aubergine including a wild type thibbatu (trilobatum), tibbatu (indicum), elabatu (Surattense), okra (Abelmoschus esculentus)and betel.

4. Incidental use: many medicinal plants such as (turmeric (Curcuma longa), ginger (Zingiber officinale), ingurupiyali (Kaemferia galanga), adatoda (Adhatoda vasica), komarica (Littoraris spp.), nika (Uitex niragundu), kuppameniya (Acalleepee nettle), wara (Calotropis gigantea) and attana (Datura fastousa)) with rubber and

5. Fixed assets: timber trees such as mahogany (Swietenia macrophylla) and jack. 


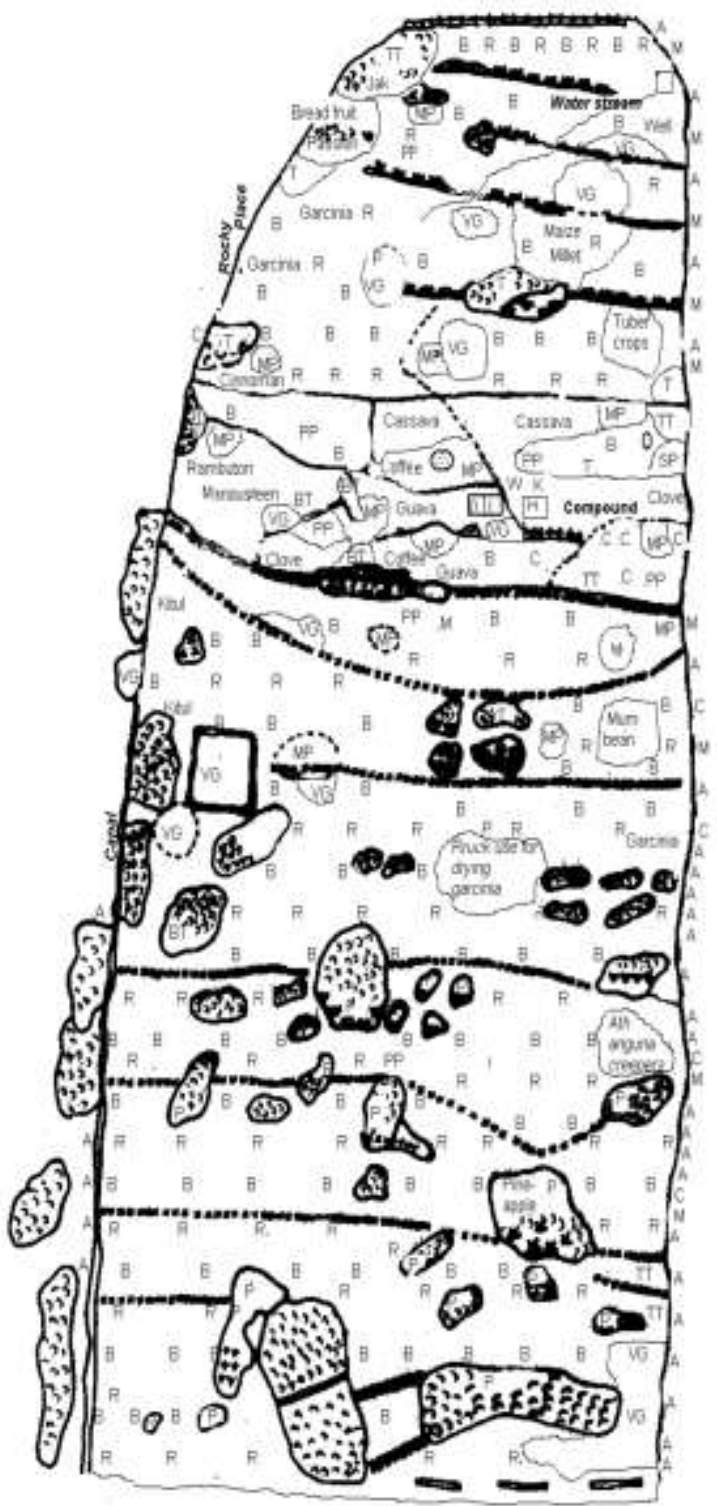

Figure 3. A farm sketch of homestead sowing the planting arrangement of trees, crops, vegetables, fruits and medicinal plants. Codes used are: $\mathrm{A}=$ arecanut, $\mathrm{B}=$ banana, $\mathrm{C}=$ coconut, $\mathrm{BT}=$ betel, $\mathrm{M}$ = mahogony, $\mathrm{PP}=$ papaya, $\mathrm{R}=$ rubber, $\mathrm{MP}=$ medicinal plants, $\mathrm{SP}=$ Sweet potatoes, $\mathrm{VG}=$ vegetables, $\mathrm{T}=$ tibbatu, $\mathrm{TT}=$ timber trees, $\mathrm{K}=$ kitchen, $\mathrm{H}=$ house, $\mathrm{W}=$ water storage. Stippled areas represent large rocks, and the home garden is shown as the area surrounding the compound. Source: Created by Author, 2014. 
This has been observed more generally, where an increase in the availability of land has resulted in a decrease in pressure on land which in turn has influenced the selection of different crops and in some cases an increase in the duration of fallow periods (Richard et al., 2001). Several authors (Buckles and Triomphe, 1999) contend that the availability of land has a significant influence on the intensity of cropping in home gardens and on rubber smallholdings. This study showed that the number of crops grown in the home gardens was significantly dependent on the size of land allocated to the crop ( $\mathrm{r} 2=0.915)$. An increase in land size resulted in a decrease in the number of crops grown for given land size in the home gardens and vice versa. However, this was partly dependent on other factors such as the length of time the farmer had lived on a particular land holding, infrastructural development, the level of income and household priorities, as has been more generally observed (Price and Campbell, 1998; Mendez et al., 2001; Stirling et al., 2002). For example, the average land size and crop diversity in home gardens was higher in Pallekiruwa than Bookandayaya, due to the availability of wellconnected markets for homegarden crops and lack of other permanent crops (Thennakkon, 2018). Price and Campbell (1998) observed that home gardens with a longer period of residence tended to have more crops grown in them.

Cropping intensity of rubber smallholdings was dependent on the availability of land. Where there was also a greater amount of land available, lower priority was given to intercropping of rubber smallholdings and vice versa as has been reported in other research in Sri Lanka (Stirling et al., 2001; Rodrigo et al., 2001b). It was evident from the case studies undertaken for the households which owned $\leq 1$ and $>1$ ha of land that those who owned $\leq 1$ ha of land, cultivated $c a$. five types of crops such as permanent crops, subsistence cereals, shortterm cash crops whilst farmers who owned $>1$ ha cultivated only rubber and in some cases banana with rubber. In accordance with explanations made by many researchers (Buckles and Triomphe, 1999; Rodrigo et al., 2001b).

\subsubsection{Land ownership}

Table 4 indicates that there was a significant relationship between crop type and land ownership class $(\mathrm{p}<0.001)$. Most of the chena crops were on state own land (43\%) followed by private (35\%) and reservation (23\%) lands. Paddy land was mostly located on private land (84\%) followed by shared land (16\%), whilst tea and citronella grass were grown solely on private land. More than $75 \%$ of rubber and banana land was classed as private land, with ca. $19-25 \%$ of banana and rubber land respectively, located on state own land. Farmers who cultivated their own land practiced a combination of short-term and permanent crops, whilst tenant smallholdings were mainly growing short-term crops (Table 4). 
Table 4: Common crops grown by smallholders according to different land ownership classes. Data show the number of smallholders within each land ownership class with corresponding percentages for each crop shown in the parentheses. Outputs from a chi-square test are shown in terms of the level of significance for the association between crop type and class of land ownership, chi-square value and degrees of freedom.

\begin{tabular}{|l|c|c|c|c|}
\hline \multirow{2}{*}{\multicolumn{1}{c|}{ Crop type }} & \multicolumn{4}{|c|}{ Land ownership } \\
\cline { 2 - 5 } & State own & Private & Reservation & Shared \\
\hline Banana & $13(19)$ & $50(76)$ & $3(5)$ & - \\
\hline Chena & $17(43)$ & $14(35)$ & $9(22)$ & - \\
\hline Citronella grass & - & $18(100)$ & - & - \\
\hline Paddy & - & $36(84)$ & - & $7(16)$ \\
\hline Rubber & $18(25)$ & $55(75)$ & - & - \\
\hline Tea & - & $19(100)$ & - & - \\
\hline P value & \multicolumn{5}{|c|}{110.74} \\
\hline Chi-square value & \multicolumn{5}{|c|}{15} \\
\hline Degrees of freedom & \multicolumn{5}{|c|}{} \\
\hline
\end{tabular}

Filius (1982) observed that where land ownership was under dispute, farmers tended to cultivate only short-term crops which could be harvested within a limited contract period, although the land was suitable for permanent crops. Ownercultivated smallholdings comprised a mixture of both short-term cash crops such as fruits (banana and pineapple) vegetables, food crops and some permanent crops (arecanut, pepper and garcinia). Tenant cultivated smallholdings, however, consisted solely of short-term crops such as fruits (banana, passion fruits and papaya), vegetables and cereals. Even within the tenant cultivation smallholdings, some differences were evident in that those farmers who mainly depended on contract farming, rather than a mixture of on- and off-farm labouring work, tended to cultivate a more diverse range of short-term cash crops instead of permanent crops as was observed previously by Ellis (1993).

\subsubsection{Proximity of cropland to homestead}

Table 5 shows that the distance to cropland differed significantly for different crop types and village location in both the Intermediate and Wet Zones. Banana and tea were grown closest to the homestead, whereas citronella grass and rubber were grown far away in Bookandayaya. Differences between villages were greater than differences between agro-climatic zones with rubber grown much closer to the homestead in the villages of Pallekiruwa and Kobawaka compared with Bookandayaya and Pannila. Similarly, the distance to chena land varied more than fivefold between Pallekiruwa and Bookandayaya (Table 5). 
Table 5: Distance between crop land and homestead for smallholdings in the villages of the Intermediate and Wet Zones. Data show the average distance $(\mathrm{km})$ together with outputs from GLM analysis of the interactions between crop type, distance and village location.

\begin{tabular}{|l|c|c|c|c|}
\hline \multicolumn{1}{|c|}{ Crop type } & Pallekiruwa & Bookandayaya & Kobawaka & Pannila \\
\hline Banana & 0.2 & 0.3 & 0.2 & 0.2 \\
\hline Chena crops & 0.3 & 1.8 & - & - \\
\hline Citronella grass & - & 2.0 & - & - \\
\hline Rubber & 0.4 & 1.6 & 0.4 & 0.6 \\
\hline Tea & - & - & 0.2 & 0.1 \\
\hline Distance *crop type & \multicolumn{5}{|c|}{$\mathrm{p}<0.001$} \\
\hline $\begin{array}{l}\text { Distance *crop } \\
\text { type*village }\end{array}$ & \multicolumn{5}{|c}{} \\
\hline
\end{tabular}

Distance of the land from the homestead had a significant effect on the selection or non-selection of cropping systems (Masae et al., 1995), in particular rubber-based intercropping systems. Of the total rubber lands intercropped with banana, short-term cash crops, pineapple and passion fruits, more than $50 \%$ were located $\leq 0.5 \mathrm{~km}$ away from the homestead. In contrast, of the total rubber lands intercropped with citronella grass and cinnamon, more than 50\% were located $>0.5 \mathrm{~km}$ away as was evidence from farmer interviews undertaken during the ethnographic study. Banana was usually cultivated at a close distance to the homestead due to susceptibility to pest damage and theft, whilst citronella grass was located far away from the home as the crop generally required less attention and risk of theft was low. If chena land located close to home, farmers can make few trips while paddy operations are in progress, since there was a close relationship between chena and paddy cultivation in terms of labour allocation (Thennakoon, 2017). Rubber smallholdings were located a far distance from the homestead and sometimes were left as sole crops, particularly where there was insufficient family labour for intercropping (Gray, 1997). Also, those crops, which required much maintenance, were located close to the homestead. Tea cropping systems required more intensive labour inputs than rubber (Thennakoon, 2017), and therefore tea was cultivated on land which was close to the homestead compared to rubber. Distance from the residence to the land was directly relevant to the level of maintenance because smallholdings located close to the home, received more visits, which in turn increased the level of maintenance (weeding, fertilizing), since farmers tended to work on the land even in their leisure 
time However, there were some exceptions where even if the land was located close to the homestead, the growth rate was low, because these smallholders gave priority to other income sources (in the Wet Zone), or soil fertility of the land was very low (in Bookandayaya), caused by cultivating citronella grass prior to establishing rubber based cropping systems (Thennakoon, 2002).

\subsubsection{Income levels and crop type}

Of the 19 tea growers, $c a$. $68 \%$ were classified as in either the high or the very high income groups whilst only 5\% were in the very low-income group. In contrast, more households cultivating rubber were in the low-income group (30\%) (Fig. 4).

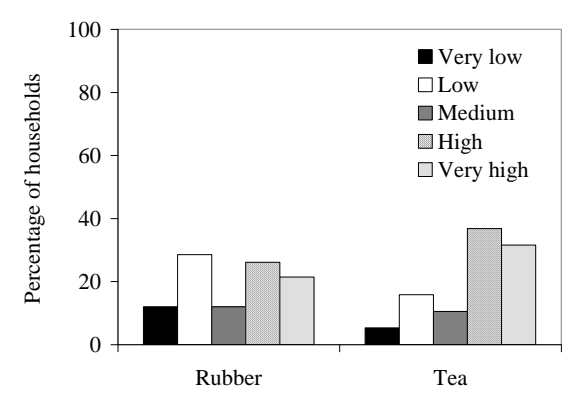

Figure 4. Distribution of rubber and tea smallholdings according to income group, where data are presented in terms of the percentage of the total number of rubber (42) and tea (19) growers sampled in the villages of Kobawaka and Pannila in the Wet Zone of Sri Lanka.

The income level of the household had a considerable influence on several factors including, selection of cropping systems, size of land holding, and allocation of land to different crops. It was evident that more labour and material consuming crops, such as tea, were cultivated mainly by very highincome households (Hassan, 1995), but no significant variations were evident for rubber, because rubber required a lower amount of labour and material inputs as has been previously mentioned by Yogaratnam et al. (1995), Samarappuli et al. (1997), Herath and Takeya (2002) and Thennakoon, (2002).

\subsubsection{Constraints to land productivity}

Many households in the Wet Zone villages stated that soil infertility and erosion were major constraints to land productivity (Pannila, 63\% and 42\%; Kobawaka 75\% and $50 \%)$. However, this was the case only for a smaller proportion of villagers in the Intermediate Zone. Also, lack of land permits was another constraint to land productivity, particularly in Pallekiruwa and Bookandayaya. The amount of land available was also a major the problem faced by farmers in Kobawaka (63\%), Bookandayaya (50\%) and Pannila (33\%), but not by farmers in Pallekiruwa (Table 6).

Soil erosion and soil fertility differed significantly between villages $X^{2}(N=96$, $\mathrm{df}=6)=54.87-34.28, \mathrm{p}<0.001$. Also, soil fertility was highly dependent on soil erosion, $\mathrm{X}^{2} \quad(\mathrm{~N}=96, \mathrm{df}=4)=41.14$, $\mathrm{p}<0.001$. Chi-square results showed that "high" soil erosion occurred in $80 \%$ and $65 \%$ of rubber smallholdings in Kobawaka and Pannila, with a much lower proportion of smallholdings in Pallekiruwa (8\%) and Bookandayaya (4\%). In contrast, soil erosion was classified as "low" in $73 \%$ and 
$50 \%$ of smallholdings in Pallekiruwa and Bookandayaya (Figure 5a). On the other hand, "high" soil fertility occurred in $68 \%$ of smallholdings in Pallekiruwa, whilst it was "low" in $76 \%, 62 \%$ and $48 \%$ of smallholdings in Kobawaka, Pannila and Bookandayaya, respectively. Not a single smallholding recorded "low" soil fertility in Pallekiruwa (Figure 5b).

Table 6: Summary of the constraints to land productivity in four villages. Data show the number of households responded for each constraint and the data in the parenthesis are corresponding percentage of the total households interviewed (24) in each village.

\begin{tabular}{|l|c|c|c|c|}
\hline Constraints & Pallekiruwa & Bookandayaya & Pannila & Kobawaka \\
\hline Infertility of soil & $2(8)$ & $12(50)$ & $15(63)$ & $18(75)$ \\
\hline Soil erosion & $5(21)$ & $4(12)$ & $10(42)$ & $12(50)$ \\
\hline $\begin{array}{l}\text { Lack of clear land } \\
\text { permits }\end{array}$ & $8(33)$ & $6(25)$ & $6(25)$ & 0 \\
\hline $\begin{array}{l}\text { Constraints to increase } \\
\text { the amount of land under } \\
\text { smallholdings }\end{array}$ & 0 & $12(50)$ & $8(33)$ & $15(63)$ \\
\hline
\end{tabular}

In the Wet Zone, land productivity was constrained by high levels of soil erosion and a low soil fertility factors which are known to restrict the growth of rubber, banana and the yield of most crops as has been reported (Vijesandiran and Samita, 1998; Neupane and Thapa, 2001; Pandeyet al., 2001; Senevirathna, 2001). Numerous researchers (Williams, 1999; Barbier, 2000; Pandey et al., 2001) elsewhere have observed that although farmers have ample knowledge of soil fertility and erosion management, in many cases this knowledge has not been put into effective use because of lack of labour, insecure tenure, low income or because farmers have other priorities. In particular, although highincome farmers can afford to do so, they prefer not to allocate labour and inputs for the protection of soil, but tend to opt for investment in growing more crops. Talgaswatte (1995) and Williams (1999) observed that high-income farmers tended to establish large farms with limited labour allocation for soil conservation methods. 


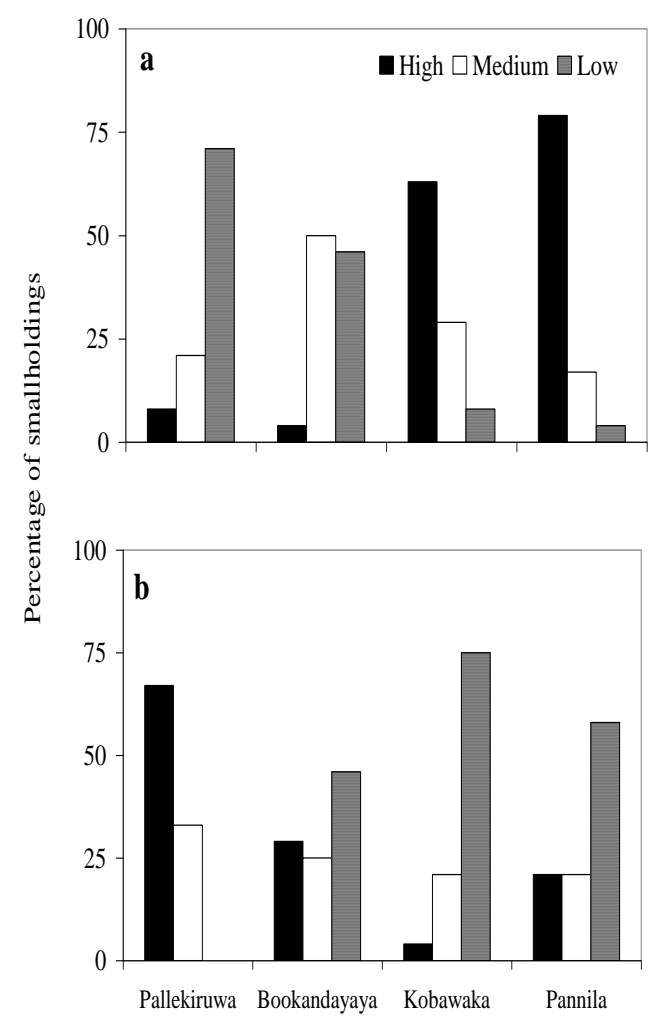

Figure 5. Summary of the problems perceived by smallholders in relation to (a) soil erosion and (b) soil fertility of rubber lands. Data are presented in terms of the percentage of the total respondents across all four villages for each of the three rankings "high", "medium" and "low" describing the severity of the problem.

\section{CONCLUSION}

The overall findings of this study are that land size, the form of land ownership, proximity to the homestead and land quality are strong driving forces in terms of which cropping systems are adopted by farmers. A decrease in land size resulted in an increase in the number of crops grown in home gardens and rubber smallholdings. Crop selection was strongly related to proximity of land to the homestead. Consequently, crops with less risk and maintenance were grown further out from homestead (e.g. citronella) and rubber compared to banana and tea. Similarly, the form of land smallholdings consisted of a mixture of intercrops (including other permanent crops), and soil protection methods were practiced, whereas tenanted farms had seasonal intercrops with less attention paid to soil protection and improvement. However, all these associations were modified by the availability of alternative income sources in a particular household.

\section{REFERENCES}

BARBIER EB. The economic linkages between rural poverty and land degradation: some evidence from Africa. Agriculture, Ecosystems and Environment. 2000; 82: 355-370.

BUCKLES D \& TRIOMPHE B. Adoption of mucana in the farming systems of northern Honduras. Agroforestry systems, 1999; 47:6791.

COMHIEL SL. SANJACK JM \& PHILLIP BR. Land tenancy in Asia, Africa and Latin America: A look at the past and a view to the future. Working Paper, Land Tenure Centre, University of Wisconsin, Maidon. No. 27; 1999. 
ELLIS, F., Peasant Economics. Farm Households and Agrarian Development. Second edition, Cambridge University press, Cambridge; 1993.

FILIUS, A.M., Economic aspects of agroforestry. Agroforestry Systems, 1982; 1:2939

HASSAN, R.M., Testing for decreasing risk aversion in traditional farming: The case of Sudan. East African Agricultural and Forestry Journal.1995; 39-45.

HERATH, P.H.M.U. AND HIROYUKI TAKEYA, Factors determining intercropping by rubber smallholders in Sri Lanka: a logit analysis. Agricultural Economics. 2003; 29: 59168. Available online at www.sciencedirect.com

KUDAGAMAGE, C., Present status of horticulture research in Sri Lanka. http://www.tropical-seeds.com/techforum/pubs-res/sl-hort-res.html; 2002. Accessed 10 March 2018

MENDEZ, V.E., LOK, R. AND SOMARRIBA, E., Interdiciplinary analysis of home gardens in Nicaragua: micro-zonation, plant use and socioeconomic importance. Agroforestry Systems. 2001; 51: 85-96.

NEUPANE, R.P. AND THAPA, G.B., Impact of agroforestry intervention on farm income under the subsistence farming system of the middle hills, Nepal. Agroforestry Systems. 2001; 53: 31-37.

PAGIOLA, S. AND HOLDEN, S., Farm Household Intensification decisions and the Environment. In: Lee, D.R. and Barrett, C.B (eds.). Tradreoffs or Synergies? Agricultural Intensification, Economic Development and the Environment. CAB International, U.K; 2001.
PANDEY, R.K., MARANVILLE, J.W. AND CRAWFORD, T.W., Agriculture Intensification and Ecological Sustainable Land use Systems in Niger: Transition from Traditional to Technologically sound practices. Research, Reviews, Practices, Policy and Technology. Journal of Sustainable Agriculture. 2001; 19 (2): 5-24.

POMP, M., Determinants of smallholder landownership-Evidence from south Sulawesi, Indonesia. Journal of Development Studies. 1995;31 (6):845-867.

RICHARD E. BILSBORROW \& CARR DL. Population, Agricultural Land Use and the Environment in Developping countries. In: Lee and Barrett (eds.). Tradeoffs or Synergies? Agricultural Intensification, Economic Development and the Environment. CABI publishing, U.K; 2001.

RODRIGO VHL THENNAKOON S. \& STIRLING CM. Priorities and objectives of smallholder rubber growers and the contribution of intercropping to livelihood strategies: a case study from Sri Lanka. Outlook on Agriculture. 2001b; 30 (4): 261-266.

RUBBER RESEARCH INSTITUTE OF SRI LANKA. RRISL. Status review report of rubber research Institute of Sri Lanka operational area, Sri Lanka Council for Agricultural Research and Policy (CARP), Colombo, Sri Lanka; 1992.

SAMARAPPULI IN. WICKRAMARATNE CS \& DIAS DGSB. Economics of reinvestment on rubber in the estate sector. Journal of the Rubber Research Institute of Sri Lanka. 1997; 79: 45-61.

SENEVIRATHNA AMWK. The Influence of Farmer Knowledge, Shade and Planting Density on Smallholder Rubber/Banana Intercropping in Sri Lanka. PhD. Thesis. School of Agricultural and Forest Sciences, University of Wales, Bangor, U.K; 2001. 
SOULE MJ. TEGENE A. \& WIEBE KD. Land Tenure and the Adoption of Conservation Practices. American Journal of Agricultural Economics. 2000; 82 (4):993-1005.

STIRLING CM. RODRIGO VHL. MARZANO M. THENNAKOON S. SILLITOE P. SENEVIRATHNA AMWK. \& SINCLAIR FL. Developing rubber-based cropping systems, that improve not only latex yield but also the livelihoods of the rural poor; a case study in Sri Lanka, The Rubber International Magazine. 2001; 3 (25): 83-89.

TALGASWATTE H. Technical efficiency of rubber production in Sri Lanka: Frontier production functions approach. PhD. Thesis. Lincoln University; 1995.

THENNAKOON TMSPK. Report on the Village Surveys relating to Intercropping on Rubber Smallholdings in Monaragala and Kalutara Districts; 1998.

THENNAKOON TMSPK. Influence of Crop profitability, Market, Labour and Land on Smallholder Cropping Systems in Rubber Growing Areas of Sri Lanka. PhD. Thesis, School of Agricultural and Forest Sciences, University of Wales, Bangor, UK; 2002.

THENNAKOON TMSPK. Influence of labour availability on smallholder cropping systems in two Agro Climatic Zones of Sri Lanka. International Journal of Multidisciplinary Education and Research. 2017; 2 (6): 39-50.

THENNAKOON TMSPK.. Influences of Market Accessibility and Price Behavior on Smallholder Cropping Systems: A Case Study in Sri Lanka. Elixir Geography. 2018; 114: 49610-49617

THOMAS P. TOMICH T.P. KILBY P. \& JHONSTON BF. Transforming Agrarian Economics: Opportunities Seized, Opportunities
Missed. Cornell University Press, Ithaca and London; 1995. p. 118-135.

VIJESANDIRAN S \& SAMITA S. Indicators of Ecological capital management in up-country tea plantations of Sri Lanka. Tropical Agricultural Research. 1998; 10: 246-253. 